\title{
FIVE LITTLE MALLARDS
}

\section{by W. G. Harstad, Box 116, Codette}

I have many vivid memories of my childhood spent three miles southeast of Codette. Much of my time was spent in the company of wild birds and animals. This was before agriculture's hunger for open space gradually changed the remaining tree land into vast fields of grain. To find wildlife as it was then, we must now go further back into the sparsely settled country. Forest-loving birds and animals no longer live with us; in their place we have those adapted to living in more open country. Although wildlife is losing ground, it does not give up easily and perhaps man will come to the rescue while we still have some of this natural beauty about us.

I recall my early fascination for discovering the well-hidden nests of wild cirds; and during the nesting seasons, hours after school and weekends were sent searching the woods for them. one of the many birds which nested, and still does, in the woods about our home is the Mallard. Each spring hese beautiful firiendly birds arrive feeming to expect the shallow runoff waters to last all summer. By hatchng time the little temporary lakes have disappeared and all that remains tre the larger more permanent loughs. The situation is even worse how, for many of these sloughs are peing drained or have dried up.

When I was in about grade three found a well concealed Mallard's hest containing eight pearly buffwhite eggs hidden in the centre of an ld willow hummock by the side of what was probably an ancient game rail. I calculated the hatching date o be somewhere in the first week of une. As this time drew near I kept a lery steady watch on the hen duck and her nest. I made hurried checks very morning before leaving for chool and again in the afternoon.

The patient hen duck became used o my daily visits and if I did not look firectly at her I could approach to within a few yards of her before she flew up through the trees, leaving her beautiful eggs lying uncovered in their soft cushion of feathers and down. I would inspect the eggs for signs of cracked shell that would indicate the efforts of the little ducks to break free of the eggs. Before leaving I would gently draw the soft feathery edge of the nest in over the eggs by using a stick or small twig which I had handled at only one end, thus avoiding the risk of leaving a trace of human odor on the nest or eggs and making sure to leave the area undisturbed as much as possible. I had learned about this egg-covering business while watching hen ducks as they left their nest to fly to a slough for a hasty drink of water and a quick meal. The duck uses her bill to draw the covering carefully over her eggs before leaving and the few dry leaves which cling to the feathery blanket make the nest practically invisible to predators looking for a meal. At the slough she would take her fill of food and water, briefly preen and bathe herself and with still damp feathers arrive back at the nest.

As hatching time drew near she became more reluctant to leave her nest, and whenever I came near, waited until the last minute before flying awkwardly along the ground, with mimicked injury trying to lead me away. Seeing that I paid no attention she anxiously walked back and forth a few yards away, quacking her protests while I quickly inspected the eggs and carefully left the scene, covering the eggs as usual.

The day of hatching finally arrived and luck was with me; it was a Saturday. On that morning the countryside was filled with a soft, misty, early summer rain. The warm lifegiving moisture falling over the land brought out the rich smell of the earth mingling with the pungent odours of dead wet trees, new wild blossoms and 
decaying leaf mold. These are the times when the forest quietly replenishes itself with new energy, and as I walked along the wooded path through the dampness of the silent falling rain, I felt even closer to my world of nature.

As I approached the familiar nest site I was filled with exciting thoughts of the wonderful things to be enjoyed with my long-planned-for ducklings. I had not tried to tame wild ducks before; little did I know how soon and how tame they would become. This time the mother duck refused to leave the nest. I walked carefully around within a few feet of her, listening to her making soft duck sounds to her newly-hatched young. I noticed a little movement of her breast feathers, and a tiny baby duck popped his head out looking at me with sharp black eyes. Hardly believing such luck as this, I moved closer. The mother was really defiant and for a moment I hesitated, remembering painfully the bravery of mother hens whenever I tried to pick up their young chicks. However, I could not give up now, and gathering extra courage I stretched my hand hand towards the brave bird; just as I was about to touch her she moved away, once again putting on his display of mock injury.

Such an entrancing sight the duck revealed when she left the nest: eight yellow and brown soft downy ducklings held warmly in the softest bed any baby thing had ever lain in. Several of the little ducklings were still damp with the moisture of newborn life. They were unafraid of me, having not yet had time to recognize the hen duck as their parent. To them I was part of their new world to be accepted readily as the object of their needs. Jarring myself into action I gathered all eight of the fluffy balls of new life gently into my cap and, carefully holding my hand over them, I hurried the short distance back to our house. Proudly I showed the prize to the rest of my family. For a moment I thought I was home-free, everything was going smoothly. Then after admiring the little beauties my mother asked the questions - Did you take all the little ducks? Was the mother still there? Answering yes both times, the reality of what I had done suddenly dawned on me. Remorsefully I thought of my selfish act, yet I could not bring myself to give them up. After considerable coaxing I was allowed to keep five. Returning to the nest with the remaining three, I found that the mother duck was still there searching for her lost young. Placing the three ducklings in the nest I retreated a short distance and watched as she came, looked them over and proudly led them off through the trees on their way to water. Hoping that she would not miss the others I hurried home to look after the new infant wild things I had adopted.

I soon had them comfortably situated in an empty grain bin. I carried in an old flat tub to hold water, placing a board in a slanting position from the floor to the edge of the tub, with another board slanting under water to the bottom on the inside, thus providing a ramp for the ducklings to waddle in and out of their artificial pond. I placed a layer of grass and straw on one section of the bin floor. They quickly learned their way around and how to get in and out of the water, doing everything as a group. I spread some crushed grain on the surface of the water and watched as they gathered it up, swimming here and there to catch the floating bits of food. Some of it became waterlogged and started to sink, providing an opportunity for my little friends to show off their expert ability at tipping up their stubby tails as they bobbed their heads under the water to gather up the slowly sinking grain.

I gave them most of my attention that day and Sunday. I ambitiously caught flies, grasshoppers and moths to give them a balanced diet. The little ducks completely accepted me as their natural parent. When I sat quietly near them while they played in the water and waddled up and down their makeshift ramp, they 
showed all the contentment of a carefully guarded brood of young under a mother's watchful eye. Tiring quickly, as all young life will, they would scramble into my lap peeping loudly if they were unable to make it until I helped them up. Here they preened themselves before gathering together under my hands to sleep momentarily. Now and then a small black eye would open, and looking me in the face a drowsy little duck would peep some duck language which I was quite sure I understood. Waking from scramble up to my face. Apparently their short nap they would try to the source of my voice was to them the key point of their affection, since as soon as they struggled to my shoulders (a task requiring some help) they snuggled under my chin and as close around my neck as poscible, peeping loudly in answer to the small talk I used whenever I was with them.

Monday morning and school came much too soon for me. I had to see that everything was in order for the ive little ducks before leaving home. hurried out to see how they had urvived the night, spent like the hight before under an arrangement of ld grain sacks simulating as much is possible the comfort of a mother luck. As I came to the door I heard saw them standing together in the eeping sounds of distress. Looking in saw them standing together in the middle of the floor very lost and frightened. They were now expecting me to stay with them constantly.

I spoke to them as they quickly gathered about my hands while I knelt to pick them up; they were all now contentedly quiet as they busily checked me from head to foot. Satisfied that I was the lost parent, they hurried up their ramp to play and feed in the tub of water. When they had grown bigger I planned to let them join the barnyard chickens for company. I could see this would soon have to be done if I were to have any freedom. Making them as comfortable as possible and leaving instructions with my mother who had been paying more than a little attention and was willing to help care for them, I left for school.

I would like to say that all the wonderful plans I had for these ducklings, who in such a short time had become so dependent and loyal to me, did come true. But I was expecting too much for them to look after themselves at night and during the day while I was at school. I had also overlooked the fact that the grain bin was far from weather-proof, and one night, a few days later a rain storm came up and the leaky roof allowed the cold moisture in to chill them. They did not survive the night and the next morning I buried their five little bodies near the nest I had taken them from.

\section{Letters and Notes}

\section{BALD EAGLES AT LA RONGE}

On April 18, 1967, Peter Gregg and went out from La Ronge to the north nd of Dominion Island to check a fish et. There were several birds at the ull hole, and as we approached to bout 200 yards one of the birds flew $p$ and we saw that is was a Bald agle. Much to our surprise the other wo birds were also Bald Eagles and ot ravens.

On April 20 we saw a Bald Eagle 1 two occasions. The second sighting, about an hour after the first, was only about a quarter of a mile from La Ronge when seen. This eagle was being harassed by a couple of ravens.

The interesting thing is that these Bald Eagle sightings are so very close to town. I've been living in La Ronge since May 1965 and had not noticed any until now.

D. Wayne Davis (Blue Jay, 24:160167, 1966) lists seven Bald Eagles reported by C. L. Ferguson as found dead at poisoned bait set intended for wolves. I know of one more which he 